5. Паращенко Л.І. Технологія формування ключових компетентностей у старшокласників: практичні підходи / Л.І.Паращенко // Компетентнісний підхід у сучасній освіті: світовий досвід та українські перспективи: Бібліотека 3 освітньої політики/ за заг. ред. О.В. Овчарук. - К.: «К.І.С.», 2004. - С.71-84.

6. Пометун О.М. Компетентнісний підхід - найважливіший орієнтир розвитку сучасної освіти/ О.М.Пометун// Рідна школа. - 2005. -№9. - С.60-65.

7. Хуторской А.В. Ключевые компетенции: технология конструирования/ А.В. Хуторской// Народное образование. - 2003. - №5. - С.55-61.

Стаття надійшла до редакції 28.05.2012 р.

УДК 378.147

В. Т. Легун, директор ДПТНЗ №7, «Навчально-виробничий иеентр», м. Кривий Ріг

\title{
КОМПЕТЕНТНІСНИЙ ПІДХІД У ПРОЦЕСІ ПРОФЕСІЙНОГО СТАНОВЛЕННЯ ОСОБИСТОСТІ МАЙБУТНЬОГО ФАХІВЦЯ
}

Легун В. Т. Компетентнісний підхід у проиесі професійного становлення особистості майбутнього фахівия.

У статті розглянуто особливості компетентнісного підходу в процесі навчання, щзо впливають на формування сойіально значущих якостей особистості майбутнього фахівия $i$ надають можливість забезпечити на достатньому рівні його професійне становлення.

Ключові слова:компетентнісний підхід, соціально значущі якості особистості, професійне становлення.

Легун В.Т. Компетентностный подход в процессе профессионального становления личности будущего спещиалиста.

В статье рассмотрены особенности компетентностного подхода в процессе обучения, которые влияют на формирование сочиально значимых качеств личности будущего специалиста и дают возможность обеспечить на достаточном уровне его профессиональное становление.

Ключевые слова: компетентностный подход, сочиально значимые качества личности, профессиональное становление.

Lehun $V$. Competence approach during professional formation of future expert.

The article discusses the features of the competency approach to learning that affect the formation of socially significant qualities of future professional and make it possible to provide a sufficient level of his professional development.

Key words: competence approach, socially significant personality traits, professional development.

Процеси глобалізаційних трансформацій, перебудови політичної, економічної, соціокультурної сфер діяльності суспільства, впровадження ринкової економіки, гостро потребують формування нової генерації фахівців. Конкурентноспроможність $є$ одним з основних показників якісного стану соціально-трудової діяльності. У зв'язку з цим актуальним є розглядання питання інноваційних технологій, які дадуть можливість забезпечити на достатньому рівні професійне становлення особистості майбутнього фахівця.

Розв'язання цієї проблеми вбачається тільки через докорінне реформування освіти в українській державі і виведення іï на рівень розвинених країн світу. Головною передумовою високого рівня розвитку особистості й невпинної інтелектуалізації нації $\epsilon$ перехід найбільш розвинених держав від індустріального виробництва до науково- 
інформаційних технологій. Саме етап науково-інформаційного розвитку виробничих технологій, основними ознаками якого $\epsilon$ «повсякчасне впровадження новітніх технологій на базі мікропроцесорної техніки i комп'ютерних засобів», зможе привести «до реального вивільнення людини 3 процесу безпосереднього виробництва» [1, с. 2].

Нині виробництво в Україні, в цілому, поки що перебуває на рівні переходу від індустріального до інформаційного. Етап індустріального розвитку виробництва не вимагав від робітників високої розумової активності. Професійна діяльність була більше побудована на фізичній активності, виробничі функції не змінювалися і визначалися вузьким колом передбачених задач і дій з чітко послідовними кроками, людина була додатком машини, яка визначала, що, як і в якому ритмі виробляти. На відміну від індустріального виробництва у виробництві, побудованому на науково-інформаційних технологіях, все вирішуватиметься самодостатністю, вмінням кожної людини на певному історичному етапі працювати по-сучасному. Освіта i наука покликані забезпечити на цьому етапі створення умов для розвитку особистості, підвищення інтелектуального потенціалу суспільства.

Розв'язання задач реформування освіти в умовах панування науковоінформаційних технологій вимагає комплексного, різнобічного підходу 3 урахуванням усіх особливостей сьогодення. Деякі з науковців (М. Аузіна, Г. Голуб, А. Возна) пов'язують свої пошуки із створенням системи формування національної еліти на основі перспективних дидактичних орієнтацій, нових теорій i концепцій, а інші (В. Зуєв, П. Осипов, О. Романовський) спираються на припущення, що розвиток вищої освіти має підпорядковуватись законам ринкової економіки, що вищій школі необхідно наповнити зміст освіти новими матеріалами, запровадити сучасні технології навчання $з$ високим рівнем інформатизації навчального процесу, вийти на творчі, ділові зв'язки із замовниками фахівця.

Ураховуючи, що у пострадянських країнах закони ринкової економіки набули досить специфічного наповнення, не можливо не погодитись 3 В. Зуєвим, який пропонує: «Перш за все здолати комплекс так званої, вузької суто спеціалізованої освіти, який постійно відтворюється в силу прагматичних, однак 3 інтерпретованих ринковою економікою поточних вимог, такого способу виробництва, де робітник об'єктивно розглядається як виробнича цінність 3 позиції його конкретної праці, хоча в узагальненому процесі виробництва йому необхідне широке «меню» компетенції» [2,c.3].

$\mathrm{y}$ численних професіографічних, педагогічних, психологічних дослідженнях, літературних джерелах, що аналізують переліки необхідних якостей того чи іншого фахівця та освітньо-кваліфікаційних характеристиках Стандартів вищої освіти саме компетенція (від лат. належність за правом коло питань, у яких володіє пізнаннями і досвідом) і компетентність (володіння компетенцією; володіння знаннями, що дозволяють робити висновок про будь-що) фахівця виносяться на одне з перших місць[6, с. 247]. Так Р. Герстенберг, керівник корпорації «Дженерал моторз», 3-поміж рис, 
притаманних керівникові виокремлює: «Компетентність. Кожен керівник має знати, як на високому рівні виконувати свою роботу» [2, с. 5]. 3 позиції розробників сучасних технологій, саме компетенція має бути результатом навчальної діяльності майбутніх фахівців у кінцевому підсумку. Вони надають ій визначення як загальній здатності, що базується на знаннях, досвіді, цінностях, здібностях, набутих завдяки навчанню.

Однією 3 ознак, притаманних ринковим відносинам, $\epsilon$ конкурентоспроможність фахівця у сфері суспільної діяльності. Саме конкурентоспроможність П. Осипов визначає як «узагальнений показник, що характеризує рівень професійної, соціальної і особистої компетенції випускника, яка забезпечує йому впевненість у власних силах і здібностях витримати конкуренцію на ринку праці у порівнянні 3 випускниками аналогічних навчальних закладів» [4, с.18].

Створення найбільш сприятливих критеріїв відбору змісту навчання та умов навчально-виховного процесу, впровадження яких дозволило б набути майбутньому молодому фахівцю оволодіти компетентністю, слід пов'язувати з розробленням моделі спеціаліста певного напрямку.

Моделювання особистості майбутнього фахівця надає змогу створити певний еталон, який дозволяє обгрунтувати зміст і визначити основні вміння та навички, необхідні спеціалісту даного профілю.

Ураховуючи, що за умов розвитку в Україні ринкової економіки і переходу до етапу науково-інформаційних технологій студентам усіх навчальних закладів належить пройти через ринок праці, актуальною $є$ розроблена П. Осиповим модель конкурентоспроможного випускника. Модель поєднує перелік інваріантних характеристик, акцентуючи, в першу чергу, увагу на необхідності широкої інформаційної, загальноосвітньої, загальнотехнічної, комп'ютерної, економічної, правової, психологічної підготовки у сполуці з глибокими вузькопрофільними, вузькопрофесійними знаннями.

Моделі спеціалістів вузького спрямування $є$ більш конкретними і тому мають більш практичну цінність.

Досить цікавою, $з$ цієї точки зору, є розроблена О. Романовським модель інженера-керівника. За основу моделювання було прийнято модель творчої особистості управлінської діяльності, розроблена В. Рибалко. Базову модель О. Романовський доповнив підструктурним блоком інженернотехнічної компетентності, що, як він зазначає, «характеризує технологічну специфіку діяльності керівника» [5,c.70]. Складники цього підструктурного блоку акцентують увагу на якостях особистості спеціаліста керівної ланки, що пов'язані з суто виробничими завданнями, а саме з:

- орієнтацією у технічній документації;

- умінням уявити нормальний хід технологічного процесу,взаємодію механізмів і приладів; визначити причини відхилень від норми;

- високою фаховою підготовкою;

- зорово-образною оперативною пам'яттю та просторовим уявленням [5, с. 72$]$. 
В окремий підструктурний блок виокремлено якості, які мають складати фахову компетентність. До цього блоку віднесено: здібність до навчання, педагогічна грамотність, компетентність у сфері керування, соціально-психологічній і кадровій.

Ураховуючи, що ВНЗ усіх рівнів акредитації готують керівний склад для різних ланок виробництва, модель інженера-керівника може бути прийнята за основу для подальшого аналізу і удосконалення у процесі розроблення моделей особистості фахівців різного рівня і більш вузького профілю.

Професійне становлення майбутніх фахівців неможливе також без формування світоглядних орієнтирів і ціннісних орієнтацій особистості, іii загальної морально-духовної культури.

Нині важливо забезпечити в навчально-виховному процесі вищого навчального закладу повноцінний розвиток особистості на шляху до утвердження високих соціально значущих якостей, духовно-моральних цінностей, на які б могли орієнтуватися майбутні фахівці. На всебічний і вільний розвиток особистості наголошується в Конституції України. Основні вимоги до формування соціально значущих якостей, формування духовноморальної культури особистості педагога знайшли своє відображення у Законі України «Про вищу освіту», Державній національній програмі «Освіта» («Україна ХХІ століття»), Концепції національного виховання, Національній доктрині розвитку освіти України, Програмі «Вчитель» тощо.

Національне виховання в Україні спрямовується на формування в молоді світоглядної свідомості, ідей, поглядів, моральних переконань, традицій та звичаїв. Державна національна програма «Освіта» («Україна XXI ст.») та Доктрина розвитку освіти в Україні визначили стратегію розвитку освіти в Україні, пріоритетні напрями та шляхи створення життєдайної системи безперервного навчання і виховання для досягнення високих освітніх рівнів, забезпечення можливостей постійного духовного самовдосконалення особистості, формування інтелектуального та культурного потенціалу як найвищої цінності нації.

Важливу роль у формуванні соціально значущих якостей особистості відіграють інформаційно-комунікативні технології, що використовуються в навчально-виховному процесі. Вони відкривають студентам доступ до нетрадиційних джерел інформації, сприяють продуктивному формуванню соціально значущих якостей особистості, досягненню розуміння необхідності вироблення i застосування нових принципів стратегії і тактики між культурної взаємодії.

Ураховуючи, хоча й повільне, але невпинне впровадження у виробничі процеси мікропроцесорної техніки і комп'ютерів, ми створюємо умови для оволодіння студентами не тільки елементами комп'ютерної грамотності, а й для набуття знань i умінь працювати 3 навчально-контролюючими програмами. Останнім вагомим внеском у цьому напрямку вважаємо розроблені нами навчально-контролюючі програми 3 методики трудового навчання (обслуговуюча та технічна праця). 
Використання їх у навчальному процесі дозволить створити для студентів на аудиторних заняттях умови максимально наближені до шкільних, допомогти їм відчути професійний рівень, престижність і значущість своєї майбутньої професії. Викладачі ж отримали дієвий інструмент у викладацькій діяльності для формування у студентів складових інженерно-педагогічної компетентності досить високого професійного рівня.

\section{Література}

1. Аузіна М.О. Система комплексної діагностики знань студентів: [навчальний посібник] / М.О Аузіна, Г.Г. Голуб, А.М. Возна. - Львів : Львівський банківський інститут НБУ, 2002. - 138c.

2. Зуєв В.М. Специаліст в условиях современного производства / В.М. Зуєв// Среднее профобразование. - 2002. - №2. - С. 2-12.

3. Козловська I.M. Теоретико методологічні аспекти знань учнів професійнотехнічної школи: дидактичні основи: [монографія] / за ред. С.У.Гончаренко/ Ірина Миколаївна Козловська. - Львів : Світ, 1999. - 302 с.

4. Осипов П.Н. ГОС СПО как условие повишенной конкурентноспособности и профессиональной мобильности випускников ССУЗов на ринке труда/ П.Н.Осипов// Среднее профессиональное образование. - 2002. - №3. - С.18-20.

5. Романовский О.Г. Сучасні підходи до проектування психолого-педагогічної моделі інженера керівника / О.Г. Романовський// Педагогіка і психологія. - 2000. - №4. C.69-78.

6. Словарь иностранних слов. - М. : Рус. яз.,1990. - 624c.

Стаття надійшла до редакції 30.04.2012 p.

T. I.Стойчик, заступник директора, Криворізький професійний гірничо-технологічний ліщей

\section{ПРОФЕСІЙНА КОМПЕТЕНТНІСТЬ ПЕДАГОГІЧНОГО ПРАЦІВНИКА В КОНТЕКСТІ СУЧАСНОЇ ОСВІТИ}

Стойчик Т. І. Професійна компетентність педагогічного прачівника в контексті сучасної освіти.

У статті розглянуто актуальну проблему вдосконалення професійної компетентності педагогічних прачівників професійно-технічних закладів освіти відповідно до сучасних вимог.

Ключові слова: компетентність, професійна компетентність, самоосвіта, підвищення кваліфікації.

Стойчик Т. И. Профессиональная компетентность педагогического работника в контексте современного образования.

В статье рассмотрено актуальную проблему усовершенствования профессиональной компетентности педагогических работников профессионально-технических заведений образования в соответствии с современными требованиями.

Ключевые слова: компетентность, профессиональная компетентность, самообразование, повышение квалификации.

Stoychik T. Professional competence of teaching staff in the context of modern education.

In the article actual problem of improvement of professional competence of teachers vocational and technical educational institutions in accordance with modern requirements.

Key words: competence, professional competence, self-education, advanced training. 